\title{
Frontiers of the Green Energy Transition
}

\author{
An Interview about Lithium Mining in South America
}

Maria Cariola

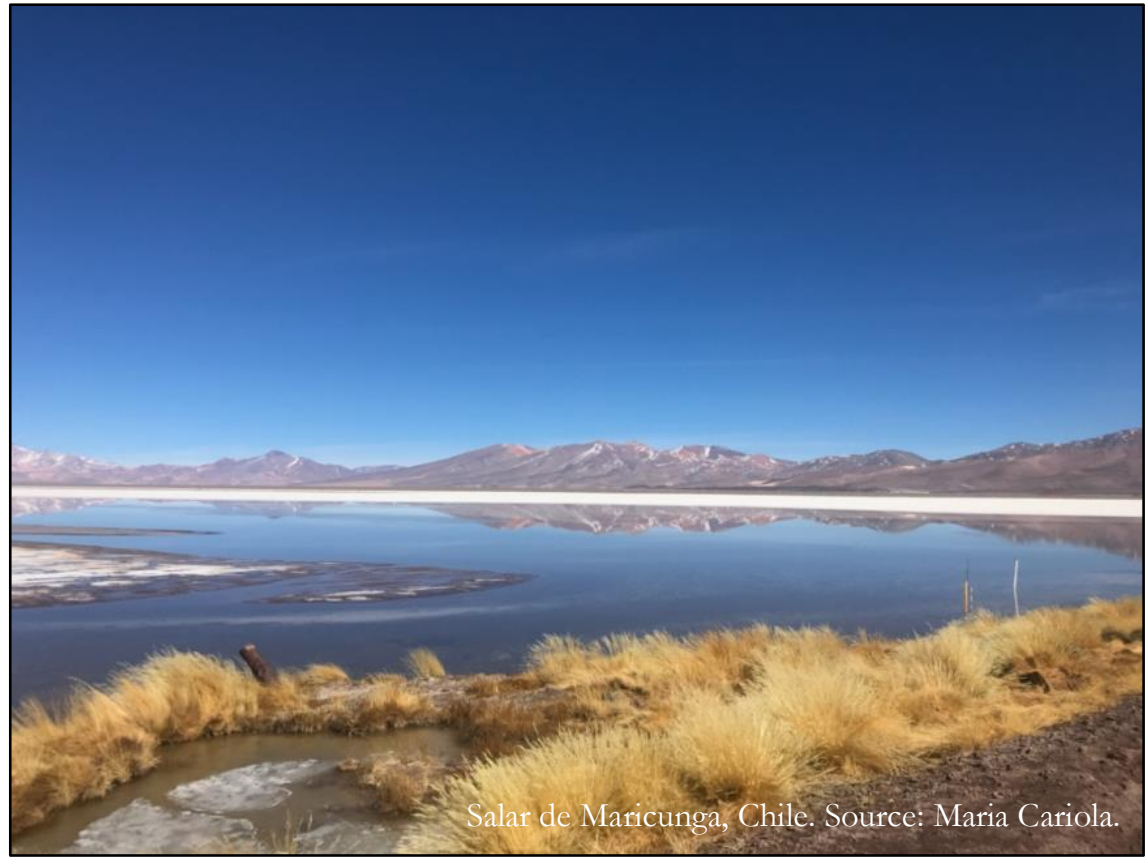

Keywords: extraction, renewable energy, Andes, geopolitics

$\mathrm{T}$

he growing consensus that the climate crisis poses an existential threat has fueled the transition away from fossil fuels. Lithium, the lightest metal on earth, is essential for storing energy in the ion-lithium batteries found in most rechargeable electric devises, including electric cars. Within this convergence between green transitions and emerging business opportunities, lithium extraction has become a frontier of the green energy transition. It has expanded rapidly throughout the past twenty years. Most of the world's known lithium reserves are

\section{Correspondence:}

Maria Cariola, maca@ifro.ku.dk

Cite this article:

Cariola, M. 2020. "Frontiers of the Green Energy Transition: An Interview about Lithium Mining in South America." Commodity Frontiers 1: 22-27. doi: 10.18174/CF.2020a17967.

Commodity Frontiers is an open-access journal edited by the CFI Editorial Board, Mindi Schneider, senior editor. Read it online at Commodity Frontiers, or our website, commodityfrontiers.com.

This work is licensed under a Creative Commons Attribution-NonCommercial 4.0 International License.

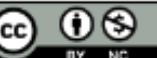


found in the salt flats of the South American altiplano in the arid and semiarid mountain landscapes between Argentina, Bolivia, and Chile. Here, lithium has transformed the brine beneath the surfaces of salt flats from being considered wastewater into possibly holding the key for the transformation of this so-called lithium triangle into what has sometimes been called the "possible Saudi Arabia of the 21 st century". But the rush of the "white gold" sparks local resistance from communities who have seen how the water-intensive extraction process is profoundly damaging the hydrological system of their homes, causing extensive droughts and thus obfuscating livelihood strategies. Meanwhile, promises of local development have yet to be fulfilled (e.g. Argento \& Puente 2019).

I interviewed Melisa Argento and Bruno Fornillo from the Research Group on Commons and Geopolitics (Grupo de Estudios Sobre Bienes Comunes y Geopolítica) at the University of Buenos Aires, Argentina. They have investigated the expansion of the lithium frontier for well over a decade, and have published widely on a range of issues, including geopolitical movements, local resistance and technological aspects of battery production.

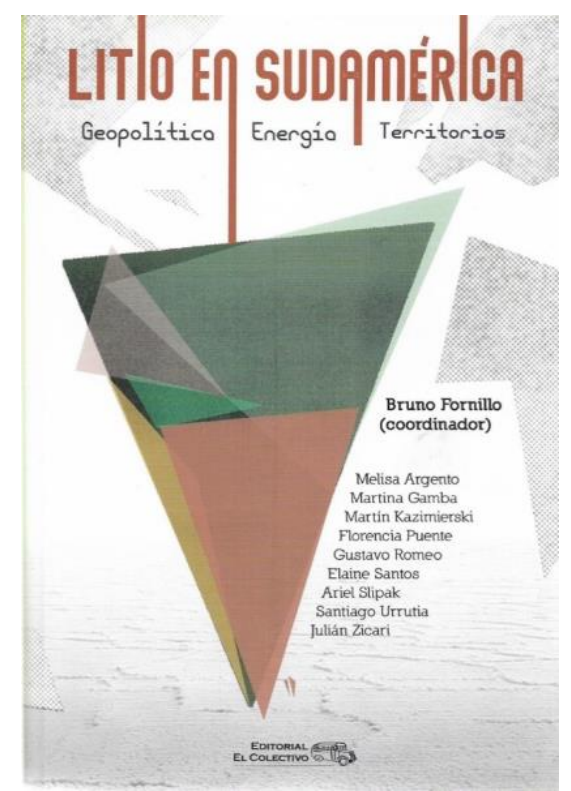

Their latest book Litio en Sudamerica: Energía, Territorio y Geopolitica (Lithium in South America: Energy, Territory, and Geopolitics) was published last year in Argentina and interrogates the politics of lithium extraction in South America.

\section{The Interview ${ }^{1}$}

María Cariola (Q): First of all, could you briefly introduce your research group?

Bruno Fornillo (BF): The group started when some of us were doing our $\mathrm{PhD}$ theses in Bolivia in 2007 and got interested in lithium. When we got back to Buenos Aires, to Argentina, we realized that Argentina also had lithium and we began investigating and thinking through these things. In the beginning we had the idea of creating a group of people with different political and academic trajectories that would be able to think collectively. That is what we have done throughout the years. We grew from initially being five members to being 12-13 today, and with diverse disciplinary backgrounds; we count among us people from chemistry, physics, history, economy, political science, environmental administration, sociology, and of different nationalities. Frankly, as a research group we have something two-faced, a little schizophrenic, but of the best of schizophrenias; we would like to be a bit like one of Pessoa's stories; one hyper-political part, another hyper-academic, and another one that no-one really knows what is.

Q: When we speak about litbium today globally and within the so-called "iithium triangle" of Argentina, Bolivia and Chile, there seems to be various desires and imaginaries involved, of energy transition, development opportunities as well as intense profits. You call it the "the very aura" of lithium, as if the mineral "were by itself charged with future". It has been called the "white gold", the oil of the 21 st century, and it has been suggested that the countries with salt flats in their territories could

\footnotetext{
${ }^{1}$ Maria Cariola conducted the interview in Spanish on 25 August 2020. She translated the text.
} 
be the Saudi Arabias of the future. You call for caution against these narratives. So, what are we talking about when we talk about lithium?

BF: It's very true that lithium, as signifier, in and of itself awakens a range of fantasies. It is an active signifier, imbued with diverse signification according to the type of approach that is realized. It is not the same for a company as it is for the communities. Lithium opens problems and hence allows for thinking through North-South relations in the parameter of exchange of a chemical element, a raw material. It allows for us to ask how different countries think of development in the present but most of all in the future. It allows for us to examine what occurs in the territorial dynamics of the communities that have inhabited the salt flats for centuries. It allows for questions into technological processes. To us, lithium is the opening into a great many pathways, and it is the indicator and pathway for thinking about a range of pressing problems in our contemporary world.

Melisa Argento (MA): In relation to that, if we were to define these multiple and narrative imaginaries, I'd say that there exist three large blocs, some of which we are interested in discussing and confronting, particularly regarding the narratives of $\mathrm{El}$ Dorado that would take lithium to be yet another resource, another commodity in the framework of opportunities for the so-called "lithium triangle". This is the classic imaginary of lithium, the "white gold". There is another line of narratives or future imaginaries that runs in the direction of the energy transition, where things get increasingly complex. Because within this framework, there are different visions. One is again absolutely commodified within the green transition or a paradigm of ecological modernization. It is only attempting to guarantee the transition for the Global North, extracting lithium from the territories and accelerating the same extractivism. This is the same as the story of El Dorado. But there are also other perspectives informed by the necessity of a just energy transition, an environmental version in which lithium could have a truly democratizing place.

BF: We have increasingly been deconstructing the image of the Saudi Arabia of lithium, in a process of initially strongly adopting it, as if this raw material in and of itself had an unusual value. In time the image lost more and more of its significance, due to different things, amongst them considering that it is really robust technological processes and the control over them that allows for generating autonomous politics with transformative capacities at a local level. I'm referring to the possibility of knowing how to make batteries, knowing how to insert those batteries into a new energy paradigm, knowing how to adapt that energy paradigm in order to foster the best conditions for equality and distribution and energy democratization in each of the countries in which the real value is. Not about having one or two raw materials. We have to do the arduous work of deconstructing the images in which the richness of Latin America is only found in its nature.

Q: The salt flats of the Altiplano are located in desert or semi-desert landscapes in very fragile bydrological ecosystems. Lithium mining is water mining, and the process of extraction requires large quantities of water, most of which evaporates along the way. What are the imminent dangers of the expansion of the lithium frontier in socioenvironmental terms?

MA: The lithium is found in the salt flats that form part of a region, a social and cultural territory, a territory with identity, which is the Atacama region. There are memories, trajectories, a common past in the populations, and forms of life that are inherently tied to a territorial process that vastly precedes the emergence of lithium as a mineral for extraction. This is the first thing that we must say to question the notion of the desert, that is very utilized in order to justify the eldoradismo in Latin America. So in these territories the 
communities argue basically that lithium mining competes with their ways of life, there usages and habits, with their knowledges, and with forms of control and collective use of the commons, including water, the salt flat, and territory.

When we say that lithium is competing [with ways of life], we want to point out that lithium extraction is pushing a boundary. Trespassing this boundary amounts to ecocide. Why? Because lithium mining is effectively water mining because of the evaporative methods employed in the brine extraction process, which today is the most profitable and hence most widespread method. What is happening is an alternation of the hydrological system of the subterranean basins beneath the salt flats. This can produce risks of droughts of water sources, watering holes, peatlands, and wetlands that are used collectively by communities for human and animal consumption and the reproduction of life. We also see salinization of these waters due to their mixing in the boundaries of the aquifers of salt- and freshwater.

Q: Your book is a critical contribution to the debate on lithium in South America, and analyses the different political and historical realities of Argentina, Bolivia and Chile. What different state strategies have been assumed in the three countries regarding lithium?

BF: Bolivia decided in 2007 that there would be state control of the whole productive chain, only making alliances in the area of high technology, which have until now fundamentally been with a German company. This process was interrupted by a coup d'état and today its destiny is uncertain. So are current Bolivian politics. Rushing to conclusions would not be worthwhile. In Chile, a distinctly Chilean combination of radical predominance of the mercantile logic coupled with long-term state policies have given rise to the formation of a National Lithium Commission. This has brought about a renewed politics regarding lithium and that generated other contracts with companies. What fundamentally appears there is the a sort of strong predominance of the economic imprint, which under the idea of Shared Value ${ }^{2}$ calls for complicity in the poor treatment of the territories of some communities, who inevitably, are in need of resources.

Argentina has a neoliberal mining code that facilitates the installation of extractive companies in mining areas, and relates directly with the provinces because the control over resources in by constitution falls on the provinces. It happens in completely asymmetrical conditions, in which the companies triumph, with scant regard to local populations. Therefore, it is in Argentina where we see the most crude plundering by the more than 50 projects in different phases.

\section{Q: And how have local communities responded to and resisted these respective strategies?}

MA: That question was what we wanted to work through in the chapter of the book that I wrote with Florencia Puente. We wanted to know what the different responses had been, repertoires of mobilization, actions, legislations in which the communities are shielding themselves in the different territories in which lithium mining is advancing. In the case of Chile, we found that the communities first encountered the companies in the 80s and 90 s, when the so-called Indigenous law was still not even in place. So you had a situation in which initially, the companies arrived and established individual, or rather, clientelist or direct relations with the communities. After that there was a framework of Corporate Social Responsibility (CSR),
${ }^{2}$ Shared Value is a doctrine of company-community relations that has advanced over the past decade. It relies on sharing economic profits with affected communities as a means of building local consent to extraction. 
which as a relational paradigm is slightly more planned, but is still clientelistic and philanthropic, with very small actual contributions to the communities. Then, with time, certain events start occurring, amongst them the complaints regarding water usage, problems with fractures of the salt flat or the collapses in the salt flat. There is also learning process of the companies, who learn over time to intervene in the territories, and move towards a logic of Shared Value which replaces the clientelism of CSR and articulates itself within the paradigm of sustainable mining. So here we have a scheme that is clearly a configuration of capital in the territories, that has its international alignments.

If you go to the Argentinian side, lithium extraction is evidently in a very initial phase. The relationship between companies and communities is much more tied to CSR in the sense that the contributions to the communities is of a very small transference of resources, a chain or participation of the communities that promises a false solution of development. It is a growth free of any type of concrete state planning of these territories. To a large degree it depends on the company-community relationship, which gives rise to a severe territorial fragmentation. This brings to the territories a logic of winner communities, that remain close to the companies, and looser communities, that are left out of that possibility.

On the other hand, we have the very different case of Bolivia. This is a genesis of a project that was articulated within the horizon of the communities and the structures and mediations of the labor unions in these territories. The fight of the 90s against Lithco established a horizon of nationalization of evaporite resources ${ }^{3}$ in these territories from the peasant sectors. In Bolivia, there is an interplay in the southeast of the Potosí region of a long mining trajectory, a history of struggle for nationalization of resources preceding and protected by the nationalization process instigated when Evo Morales and MAS (Movimiento al Socialismo) rose to power.

Effectively, regarding the entirety of the ecosystem and the hydric equilibrium of these territories, you can see that in Chile the demands are much more radicalized, because of the passing of time and the different articulations with the companies. In the case of Argentina, there are demands related to two key bodies of law, which is the indigenous legislation, the demand for the compliance with the Free, Prior and Informed Consultation, but also the environmental law. On the other hand, you have the case of Bolivia, where really, due to the history of the project, you do not see demands framed within the indigenous question for the recognition of communities and peoples and first nations, nor do you see environmental demands. In any case, and I will close with this, what we have seen lately is that there is also today a demand of some communities with bonds to the Civic Committee of Potosí. They oppose the project and fundamentally oppose the hegemonic role of the national government and $\mathrm{La} \mathrm{Paz}$ in a very strong departmental dispute. This is strongly related to the mobilizations over the past year against Evo Morales and also strongly related to a historical question in which the Committee, having been protagonist over so many years in the demands related to lithium, reclaiming the tax as rightfully belonging to them.

\footnotetext{
${ }^{3}$ Evaporite minerals like the brine containing lithium found on the high-altitude salt flats are formed through solar evaporation.

${ }^{4}$ Civic entity conformed by members representing diverse institutions of the Potosí and civil society,
}

and has played a crucial role throughout the past decades in disputing transnational control over natural resources of the department. 


\section{References}

Argento, Melisa \& Florencia Puente. 2019. Entre el boom del litio y la defensa de la vida. Salares, agua, territorios y comunidades en la región atacameña. In: Litio en Sudamérica. Geopolítica, Energía, Territorios. Ed. B. Fornillo, 173-222. Buenos Aires: El Colectivo; CLACSO; IEALC - Instituto de Estudios de América Latina y el Caribe.

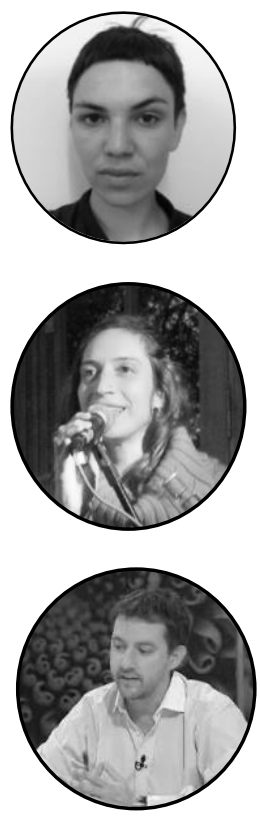

Maria Cariola Eriksson is a PhD student at the Department of Food and Resource Economics, University of Copenhagen.

Melisa Argento is a PhD student at the Institute for Latin American and Caribbean Studies at the University of Buenos Aires (UBA). She works on conflicts over mineral extraction in Bolivia and Ecuador.

Bruno Fornillo holds a PhD in Social Sciences from the University of Buenos Aires (UBA) and in Geopolitics from the University of Paris 8. He is a researcher from CONICET (National Council of Scientific and Technical Research) in Argentina, and forms part of the Institute for Latin American and Caribbean Studies at UBA. He works on contemporary Bolivian history and natural resources, geopolitics and energy in South America. 